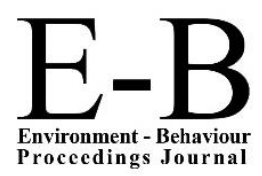

\title{
AicE-Bs2016Edinburgh
}

$7^{\text {th }}$ Asia-Pacific International Conference on Environment-Behaviour Studies, St Leonard Hall, Edinburgh University, United Kingdom, 27-30 July 2016

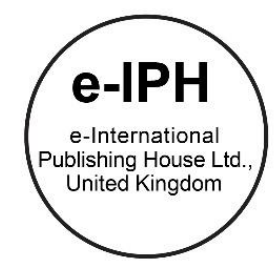

\section{Manifestation of work-life balance in the Malaysian banking workforce: Transformational leadership the potent enabler}

\author{
Azzarina Zakaria *1, Muhamad Khalil Omar 2 \\ ${ }^{1}$ Faculty of Business and Management, Universiti Teknologi MARA, Shah Alam, 40450, Malaysia \\ ${ }^{2}$ Faculty of Business and Management, Universiti Teknologi MARA, Bandar Puncak Alam, 42300, Malaysia
}

\begin{abstract}
Baby Boomers are soon reaching their retirement and the workforce vacancies will inevitably occupied by the Xers and Millennials. The two younger cohorts are drastically different from their senior echelon where work-life balance is of utmost important to them. Transformational leadership is claimed as the potent enabler to the practice of work-life balance. Consequently, this study aimed to examine the extent of the relationship between the two. Questionnaires were distributed to two domestic banks. Findings reported the relationship between transformational leadership and work-life balance. No differences, however, are shown between demographic profiles of gender, marital status and age about work-life balance.
\end{abstract}

(c) 2016. The Authors. Published for AMER ABRA by e-International Publishing House, Ltd., UK. This is an open access article under the CC BYNC-ND license (http://creativecommons.org/licenses/by-nc-nd/4.0/).

Peer-review under responsibility of AMER (Association of Malaysian Environment-Behaviour Researchers), ABRA (Association of Behavioural Researchers on Asians) and CE-Bs (Centre for Environment-Behaviour Studies), Faculty of Architecture, Planning \& Surveying, Universiti Teknologi MARA, Malaysia.

Keywords: Work-life balace; Transformational leadership; Banking

\section{Introduction}

This study investigates work-life balance and its relation to the construct of transformational leadership within the context of the banking industry in Malaysia. The merit to disentangle the concept of work-life balance is rooted from the concern of aging workforce (considering that the Baby Boomers who currently represent the majority of the current workforce will be soon reaching their retirement threshold). As a result of these, the emergence of demographic shift is expected, leaving the Xers and the new entrant of Millennials to occupy the current workforce. It is contended that the two generations embrace flexibility within the employment relationship than the Baby Boomers, thus make it particularly valuable to extend the body of evidence in this field. Work-life balance is, however,

\footnotetext{
* Corresponding author. Tel.: +6013-2041977

E-mail address: azzarina@salam.uit.edu.my
}

2398-4287 @ 2016. The Authors. Published for AMER ABRA by e-International Publishing House, Ltd., UK. This is an open access article under the CC BY-NC-ND license (http://creativecommons.org/licenses/by-nc-nd/4.0/).

Peer-review under responsibility of AMER (Association of Malaysian Environment-Behaviour Researchers), ABRA (Association of Behavioural Researchers on Asians) and CE-Bs (Centre for Environment-Behaviour Studies), Faculty of Architecture, Planning \& Surveying, Universiti Teknologi MARA, Malaysia.

DOI: http://dx.doi.org/10.21834/e-bpj.v1i4.388 
subjected to some influencing factors. Among the potential factor is transformational leadership and it is argued to be the potent enabler to the success of work-life balance in an organization.

\section{Literature review}

\subsection{Work-life balance}

The work-life balance concept is an extension of the study of work-family balance that took place in the late 1990s which look into the positive interaction between work and family elements. In the 2000s, researcher started to extend to the concept of work-life balance that considers of other non-family (e.g., pleasure, health, community activities, voluntary work, hobbies and spiritual development) in addition to the family elements (Kumarasamy, Pangil \& Isa, 2015; Parakandi \& Behery, 2016). The inclusion of non-family elements, therefore, made the work-life balance much comprehensive, and it is considered more relevant to apply to all employees irrespective of marital or parental status (Omar \& Zakaria, 2015).

The phrase work-life balance consists of two conjoining requisites: (1) work-life and (2) balance. The former composes of a broader construct, which includes the nexus between two domains of paid work and non-work activities while the latter reflects the equilibrium between the two domains (Omar \& Zakaria, 2015). Collectively, work-life balance is a state of equilibrium achieved between the work life and personal life of employees (Parakandi \& Behery, 2016). From the perspective of most employees, they would see that their work place obligations and nonwork activities (family, community activities, leisure and recreation) as a set of cognitive elements that must be in the state of balanced and thus need to be managed effectively (Kumarasamy et al., 2015).

Dash, Anand, and Gangadharan (2012) found no significance in the differences of work-life balance among demographic groups of gender, age, marital and job position. The study, therefore, confirmed that work-life balance as a gender, age, marital, and job position is rather a neutral construct, despite many frequently perceived women, adults, married and those having more family and job responsibilities as persons who require more work-life balance. It further signifies that work-life balance is a state of experience that is appreciated by any individual of employees irrespective their demographic profiles. It should be noted that the current study differs from Dash et al. (2012) in terms of the setting (banking employees instead of IT professionals) and the focus of the study (work-life balance in relation to transformational leadership instead of demographic perspectives).

The work-life imbalance has been associated with negative consequences. It could cause depression and stress related problems (Kumarasamy et al., 2015) and physical wellbeing problems (e.g., coronary heart disease) (Kinman \& Jones, 2003) that could lead to errors and inefficacy. Research also linked work-life imbalance to job dissatisfaction, job burnout and turnover intention (Shanafelt et al., 2016). Implementation of work-life balance initiative, however, has proven to bring positive organizational outcomes. These include improved employee retention, employee engagement, employee commitment, and improved labor recruitment (Adame, Caplliure \& José Miquel, 2016).

\subsection{Transformational leadership and work-life balance}

Literature articulates that work-life balance is subjected to some influencing factors. Common factors noted in literature are organizational culture, policies, leadership, job autonomy, emotional intelligence and technology advancement (Adame et al., 2016; Kumarasamy et al., 2015). Among these, leadership has been claimed to be the potent enabling factor to work-life balance (Drew \& Murtagh, 2005). Supportive and transformational leadership are the two frequently argued to be relevant to work-life balance (Syrek, Apostel \& Antoni, 2013).

The study, therefore, endeavors to disentangle the concepts of work-life balance and leadership behavior specifically into transformational leadership. The emphasis is due to the potential of the very nature of transformational leadership that could amplify the application of work life balance through its four unique but 
interrelated behavioral dimensions of idealized influence (the process where the leader instills pride, faith, and respect), inspirational motivation (the leader motivates and inspires followers), intellectual stimulation (the process of leader emphasizes follower to think in new ways and the use of reasoning before taken action) and individualized consideration (a process of which leader treats each follower as an individual) dimension (Bass, 1990).

Transformational leaders encourage employees to reframe challenging situations into new perspective (parallel to intellectual stimulation dimension) (Bakker \& Demerouti, 2007). They continuously empower employees, where employees will learn new behaviors and develop skills to cope with pressure (consistent to intellectual stimulation dimension) and becomes more controllable, should then lead to less exhaustion and more satisfaction with the balance between work and non-work demands (Syrek et al., 2013). Additionally, transformational leaders pay special attention to their followers' individual needs and personify organization as caring to emphasize on individual well-being and valuing their individual considerations (individualized consideration dimension) (Wang \& Walumbwa, 2007). Transformational leaders are also attentive to employees' needs for recognition, which encourages employees to continue in the chosen direction and helps to maintain motivation despite the stressful situation (inspirational motivation dimension) (Bakker \& Demerouti, 2007). Most importantly, transformational leaders communicate a sense of purpose, which helps employees to comprehend the development of the stressful situation (idealized influence dimension) (Rowold \& Schlotz, 2009). Based on the above arguments, the following five hypotheses are thus put forward:

Hypothesis 1 (H1):

The transformational leadership dimension of idealized influence will positively associate with work-life balance.

Hypothesis $2(\mathrm{H} 2)$ :

The transformational leadership dimension of inspirational motivation will positively associate with work-life balance. Hypothesis $3(\mathrm{H} 3)$ :

The transformational leadership dimension of intellectual stimulation will positively associate with work-life balance. Hypothesis $4(\mathrm{H} 4)$ :

The transformational leadership dimension of individualized consideration will positively associate with work-life balance.

Hypothesis $5(\mathrm{H} 5)$ :

Overall, transformational leadership will positively associate with work-life balance.

A conceptual framework that illustrates the above hypotheses is as follows:

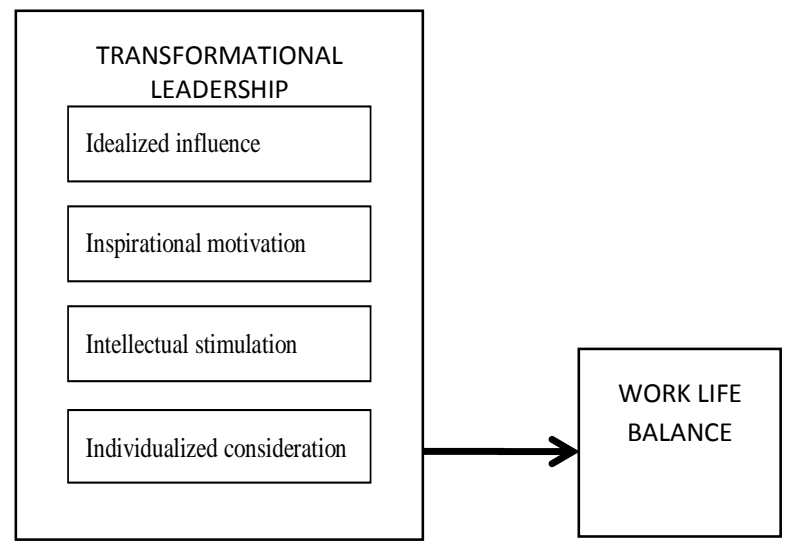

Figure 1: Conceptual framework of the study 


\subsection{Generational groups in the current workforce}

Three major generational groups composed of the current workforce: Baby Boomers, Generation X (from now on Xers) and Generation $Y$ (from now on Millennials). These three cohorts have been claimed to be different regarding their work values, attitudes, expectations and preferences (Beutell \& Wittig-Bermen, 2008). Baby Boomers (born in 1946-1964) are those who value hard works, long hours and commitment whilst the two younger generations i.e. Xers (born in 1965-1980) and Millennials (born in 1981-2000) however are rather short-termism, focus more on personal development and work-life balance than organisational loyalty (Dessler, 2015).

The current workforce is argued in the state of aging (Dessler, 2015). Baby boomers who are the largest source of labor participation in the current workforce are soon to be on the threshold of retirement and the vacancies will be left to occupy by the two younger cohorts of Xers and Millennials. Since the two younger cohorts are distinctly different from their senior echelon, structural and policies changes that incorporate flexibility may require to attract and retain those two generations.

\subsection{Malaysian banking}

The Malaysian banking landscape has been drastically evolved since the deregulation of Banking Acts in Malaysia introduced. The influx of the gigantic foreign banking institutions in the industry is among the notable effects derives from the deregulation exercise. Equipped with greater capital, technology, and experiences, these foreign banking institutions have intensified the state of competition in the Malaysian banking, putting higher risk to the domestic banking institutions to exit the industry.

To defend their position, domestic banking institutions are expected to consider alternative differentiated strategies for customization and personalization of services. More commitments are therefore expected from the employees; whereby incidences of longer working hours and more deadlines are becoming the job routines. These natures of work arrangement, however, are conflicting to the values embraced by the Xers and Millennials. Alongside the retirement of Baby Boomers in near future, ignoring the work values of the two younger echelons is thus not considered as a good gesture for the domestic banking institutions. Employment arrangement that could fit the needs of the younger echelons should be designed. Otherwise, turnover might be an emerging issue which after that detrimental to the attainment of the business strategies.

\section{Methodology}

\subsection{Sample and Procedures}

The study participants were the head office employees of two domestic banks in Malaysia. Distributions of the questionnaires to the employees were done by a liaison officer (Human Resource Department) appointed by both banks. The arrangement was agreed upon prior the data collection that distribution of questionnaires should be handled by their Human Resource department (to avoid any possible interruption their business operations). The researcher then had made to understand by the two liaison officers that the questionnaires were distributed to all their employees based in the head office. The survey yielded a total of 102 questionnaires. Each of the returned questionnaires was found to be completed and useful for analysis.

\subsection{Measurements}

The scales used in the questionnaire measured transformational leadership and work-life balance and were adopted from validated scales made available in the literature. Transformational leadership was measured using the instrument of Bass and Avolio (1992) widely known as Multifactor Leadership Questionnaire (MLQ), the shortened 
form version MLQ-6S. It had 12 statements for four dimensions idealized influence, inspirational motivation, intellectual stimulation and individualized consideration that scored on five-point Likert scale (not at all, once in a while, sometimes, fairly often and frequently, if not always). Work-life balance, on the other hand, was onedimensional and adopted from Valcour (2007). It composed of seven items and was scored on seven-point Likert scale (strongly agree, disagree, slightly disagree, neither agree nor disagree, slightly agree, agree and strongly agree).

\section{Results}

Table 1 below provides the personal demographic information of the study respondents. An equal number of males and females participated in the study. It was noted that majority of the respondents (approximately 82 percent) were Xers and Millennials. Most of the respondents were married and attached as officer positions. Human resource department was the highest contributor for the study participation. It was not surprising since the liaison officers handled for the questionnaires distribution were attached to Human Resource Department.

Table 1: Personal demographic information for the respondents

\begin{tabular}{|c|c|c|c|}
\hline & & $\mathrm{N}=102$ & \\
\hline Demographic & Category & Frequency & Percentage \\
\hline \multirow{3}{*}{ Gender } & Male & 51 & 50 \\
\hline & Female & 51 & 50 \\
\hline & TOTAL & 102 & 100 \\
\hline \multirow[t]{6}{*}{ Age } & Below 20 years old & 2 & 2 \\
\hline & $21-30$ years old & 47 & 46 \\
\hline & $31-40$ years old & 35 & 34 \\
\hline & $41-50$ years old & 18 & 18 \\
\hline & 51 years old and above & 0 & 0 \\
\hline & TOTAL & 102 & 100 \\
\hline \multirow[t]{4}{*}{ Marital status } & Single & 40 & 39 \\
\hline & Married & 61 & 60 \\
\hline & Others & 1 & 1 \\
\hline & TOTAL & 102 & 100 \\
\hline \multirow[t]{7}{*}{ Position } & Manager & 26 & 25 \\
\hline & Assistant manager & 13 & 13 \\
\hline & Officer & 36 & 35 \\
\hline & Clerical & 20 & 20 \\
\hline & Non-clerical & 1 & 1 \\
\hline & Others & 6 & 6 \\
\hline & TOTAL & 102 & 100 \\
\hline \multirow[t]{8}{*}{ Department } & Branches & 1 & 1 \\
\hline & Finance/Audit & 7 & 7 \\
\hline & IT & 7 & 7 \\
\hline & Customer service & 10 & 10 \\
\hline & Sales/marketing & 6 & 6 \\
\hline & Human Resources & 43 & 42 \\
\hline & Others & 28 & 27 \\
\hline & TOTAL & 102 & 100 \\
\hline
\end{tabular}

For a study that is quantitative in nature, it is important to seek for scales that reliable. One of the most commonly used indicators for reliability is known as Cronbach's alpha coefficient, and the ideal value should be above 0.70 (DeVellis, 2012). The study, therefore, had run the reliability test for the two constructs of the study i.e. transformational leadership and work-life balance. Finding reported Cronbach's alpha coefficient value of 0.93 and 0.95 respectively. Both exceeded the threshold value of 0.70 indicating good internal consistency among the items of the two constructs. The results may be attributed to the fact that the two constructs adopted well-validated measurements. 
Table 2: Correlations matrix for the four dimensions of transformational leadership and work-life balance

\begin{tabular}{|l|l|l|l|l|c|c|}
\hline \multicolumn{2}{|c|}{} & $\begin{array}{l}\text { Work-life } \\
\text { balance }\end{array}$ & $\begin{array}{l}\text { Idealized } \\
\text { influence }\end{array}$ & $\begin{array}{l}\text { Inspirational } \\
\text { motivation }\end{array}$ & $\begin{array}{l}\text { Intellectual } \\
\text { stimulation }\end{array}$ & $\begin{array}{l}\text { Individualized } \\
\text { consideration }\end{array}$ \\
\hline \multirow{2}{*}{$\begin{array}{l}\text { Work-life } \\
\text { balance }\end{array}$} & $\begin{array}{l}\text { Pearson } \\
\text { Correlation }\end{array}$ & 1 & .190 & $.262^{* *}$ & .174 & $.244^{*}$ \\
\cline { 2 - 7 } & Sig. (2-tailed) & & .056 & .008 & .081 & .014 \\
\cline { 2 - 7 } & $\mathrm{N}$ & 102 & 102 & 102 & 102 & 102 \\
\hline
\end{tabular}

${ }^{* *}$. Correlation is significant at the 0.01 level (2-tailed).

*. Correlation is significant at the 0.05 level (2-tailed).

Table 2 above shows the correlations matrix of work-life balance and the four dimensions of transformational leadership: idealized influence, inspirational motivation, intellectual stimulation and individualized consideration. Results suggest support for two hypotheses where small, positive correlations were reported for work-life balance and inspirational motivation $(\mathrm{H} 2)(r=.244, n=102, p<0.05)$ and work-life balance and individualized consideration $(\mathrm{H} 4)(r=.262, n=102, p<0.01)$. Contrary to the expectation, $\mathrm{H} 1(r=.190, n=102, p=.056)$ and $\mathrm{H} 3(r=.174, n=$ $102, p=.081$ ) were rejected.

Table 3: Correlations matrix for transformational leadership and work-life balance

\begin{tabular}{|l|l|l|l|}
\hline \multicolumn{2}{|c|}{} & Transformational leadership & Work-life balance \\
\hline \multirow{3}{*}{ Transformational leadership } & Pearson correlation & 1 & $.237^{*}$ \\
\cline { 2 - 4 } & Sig. (2-tailed) & & .017 \\
\cline { 2 - 4 } & $\mathrm{N}$ & 102 & 102 \\
\hline
\end{tabular}

*. Correlation is significant at the 0.05 level (2-tailed).

Table 3 on the other hand, provides the results of Pearson correlation for transformational leadership and worklife balance. H5 was apparently supported with small and positive correlation reported $(r=.237, n=102, p<0.05)$.

Additional analyses were conducted to examine the differences between demographic profiles of gender, marital status and age in relation to work-life balance. As explained in the independent-samples t-test (Table 4 and Table 5), no significant difference was reported in work-life balance scores for males $(M=5.38, S D=0.779)$ and females $(M=$ 5.22, $S D=0.873 ; t(100)=0.975, p=0.332$, two-tailed).

Table 4: Group Statistics (gender and work-life balance)

\begin{tabular}{|l|l|l|l|l|l|}
\hline & Gender & $\mathrm{N}$ & Mean & Standard deviation & Standard error mean \\
\hline \multirow{2}{*}{ Work-life balance } & Male & 51 & 5.38 & 0.779 & 0.109 \\
\cline { 2 - 6 } & Female & 51 & 5.22 & 0.873 & 0.122 \\
\hline
\end{tabular}

Table 5: Independent Samples Test (gender and work-life balance)

\begin{tabular}{|c|c|c|c|c|c|c|c|c|c|c|}
\hline & & \multicolumn{5}{|c|}{ Levene's Test for Equality of Variances } & \multicolumn{4}{|c|}{ T-test for equality of means } \\
\hline & & & & & & & & & $\begin{array}{l}95 \% \text { confiff } \\
\text { of the diffe }\end{array}$ & e interval \\
\hline & & $\mathrm{F}$ & Sig. & $T$ & $\mathrm{Df}$ & $\begin{array}{l}\text { Sig (2- } \\
\text { tailed) }\end{array}$ & $\begin{array}{l}\text { Mean } \\
\text { difference }\end{array}$ & $\begin{array}{l}\text { Standard } \\
\text { error } \\
\text { difference }\end{array}$ & Lower & Upper \\
\hline $\begin{array}{l}\text { Work-life } \\
\text { balance }\end{array}$ & $\begin{array}{l}\text { Equal } \\
\text { variances } \\
\text { assumed }\end{array}$ & 1.203 & 0.275 & 0.975 & 100 & 0.332 & 0.160 & 0.164 & -0.165 & 0.485 \\
\hline & $\begin{array}{l}\text { Equal } \\
\text { variances } \\
\text { not } \\
\text { assumed }\end{array}$ & & & 0.975 & 98.726 & 0.332 & 0.160 & 0.164 & -0.165 & 0.485 \\
\hline
\end{tabular}


Similar results were reflected for marital status (Table 6 and Table 7), no differences between the marital status single $(M=5.27, S D=0.819)$ and married pertaining to the work-life balance score (Table 4$):(M=5.31, S D=0.839$; $t(100)=-0.271, p=0.787$, two-tailed).

Table 6: Group Statistics (marital status and work-life balance)

\begin{tabular}{|l|l|l|l|l|l|}
\hline & Gender & N & Mean & Standard deviation & Standard error mean \\
\hline \multirow{2}{*}{ Work-life balance } & Single & 41 & 5.27 & 0.819 & 0.128 \\
\cline { 2 - 6 } & Married & 61 & 5.31 & 0.839 & 0.107 \\
\hline
\end{tabular}

Table 7: Independent Samples Test (marital status and work-life balance)

\begin{tabular}{|c|c|c|c|c|c|c|c|c|c|c|}
\hline & & \multicolumn{5}{|c|}{ Levene's Test for Equality of Variances } & \multicolumn{4}{|c|}{ T-test for equality of means } \\
\hline & & \multirow[b]{2}{*}{$\mathrm{F}$} & \multirow[b]{2}{*}{ Sig. } & \multirow[b]{2}{*}{$T$} & \multirow[b]{2}{*}{ Df } & \multirow[b]{2}{*}{$\begin{array}{l}\text { Sig }(2- \\
\text { tailed })\end{array}$} & \multirow[b]{2}{*}{$\begin{array}{l}\text { Mean } \\
\text { difference }\end{array}$} & \multirow[b]{2}{*}{$\begin{array}{l}\text { Standard } \\
\text { error } \\
\text { difference }\end{array}$} & \multicolumn{2}{|c|}{$\begin{array}{l}95 \% \text { confidence interval } \\
\text { of the difference }\end{array}$} \\
\hline & & & & & & & & & Lower & Upper \\
\hline \multirow[t]{2}{*}{$\begin{array}{l}\text { Work-life } \\
\text { balance }\end{array}$} & $\begin{array}{l}\text { Equal } \\
\text { variances } \\
\text { assumed }\end{array}$ & 0.087 & 0.768 & -0.271 & 100 & 0.787 & -0.046 & 0.168 & -0.378 & 0.287 \\
\hline & $\begin{array}{l}\text { Equal } \\
\text { variances } \\
\text { not } \\
\text { assumed }\end{array}$ & & & -0.273 & 87.336 & 0.786 & -0.046 & 0.167 & -0.377 & 0.286 \\
\hline
\end{tabular}

A one-way between-groups analysis of variance (ANOVA) was performed to examine the differences between age groups on scores of work-life balance. As shown in Table 8, there were no differences revealed for the three age groups investigated: below 30 years old; 31-40 years old and 41 years and above: $F(2,99)=0.247, p=0.782$.

Table 8: One-way between-groups ANOVA (age groups and work-life balance)

\begin{tabular}{|l|l|l|l|l|c|}
\hline Work-life balance & Sum of squares & Df & Mean square & F & Sig. \\
\hline Between groups & 0.342 & 2 & 0.171 & 0.247 & 0.782 \\
\hline Within groups & 68.729 & 99 & 0.694 & & \\
\hline \multicolumn{1}{|c|}{ Total } & 69.072 & 101 & & & \\
\hline
\end{tabular}

It should be observed that the results of the demographic profiles of gender, marital status and age in relation to work-life balance were found to be consistent with the previous empirical study (i.e. Desh et al., 2012), consequently ascertains work-life balance as a neutral construct.

\section{Discussion and Conclusion}

Findings reported the evident of the relationship between transformational leadership and work-life balance. Additionally, no differences are shown between demographic profiles of age, gender and marital status and work-life balance. These findings are parallel to the previous empirical research thus providing further supports to the literature. Since the study focuses on two domestic banks in Malaysia, the findings discussed herein should be cautiously interpreted in terms of its generalizability. The findings consequently denote several fruitful implications to the employers. First, work- life balance is no longer an issue that should be addressed to the younger (Xers and Millennials) cohorts; instead, it should be viewed collectively from all cohorts of employment (since no differences reported for age groups about work-life balance). Second, employer needs to find a fit between the expectations of younger cohorts and the business strategies. Business strategies that embedded flexibility and supportive working 
arrangement should be considered instead. It is unavoidable since the older cohort is soon leaving the workforce (most of the study participants were Xers and Millennials). Since transformational leadership has been empirically shown to be relevant to work-life balance, employers, therefore, should reorient their leadership to transformational leadership. Initiatives that encourage and develop transformational leaders in the organization should be formulated. This leadership is not only able to personify the younger cohorts but also claimed in spearheading the organizations to success.

Further research could be positioned from this study. Though the current study investigates work-life balance to an extent, a much focus study that specifically looks into the work-life balance from the experience of employees with special needs children in Malaysia is relatively ignored. Since special needs children require more attention regarding healthcare, financial and efforts, achieving a state of work-life balance seems to be enormously challenging for employees with the special needs children. A comprehensive qualitative study investigates into this cohort of employees should be undertaken to reveal their current state of work-life balance, consequently to propose a framework of work arrangement where multiple caregiving and employment responsibilities can successfully fit together.

\section{Acknowledgements}

This research is funded under the Research Acculturation Grant Scheme from Ministry of Higher Education Malaysia. This research is also supported by the Universiti Teknologi MARA, Shah Alam, Malaysia.

\section{References}

Adame, C., Caplliure, E., \& José Miquel, M. (2016). Work-life balance and firms: A matter of women?. Journal of Business Research, 69(4), 13701383.

Bass, B.M. (1990). Handbook of leadership: Theory, research \& management applications (3 $3^{\text {rd }}$ ed.). New York: The Free Press.

Bass, B. M., \& Avolio, B. J. (1992). Multifactor leadership questionnaire-short form 6S. Binghamton, NY: Center for Leadership Studies.

Bakker, A.B., \& Demerouti, E. (2007). The job demands-resources model: States of the Art. Journal of Managerial Psychology, 22, 309-328.

Beutell, N. J., \& Wittig-Berman, U. (2008). Work-family conflict and work-family synergy for generation X, baby boomers, and matures: Generational differences, predictors, and satisfaction outcomes. Journal of Managerial Psychology, 23(5), 507-523.

Dash, M., Anand, V., \& Gangadharan, A. (2012). Perceptions of work-life balance among IT professionals. The IUP Journal of Organizational Behavior, XI(1), 51-65.

Dessler, G. (2015). Human Resource Management. Boston: Pearson.

DeVellis, R.F. (2012. Scale development: Theory and applications (3rd edition). Thousand Oaks, California: Sage.

Drew, M., \& Murtagh, A.M. (2005). Work-life balance: Senior management champions or laggards, Women in Management Review, 20(4), 262278.

Kinman, G., \& Jones, F. (2003). 'Running up the down escalator': Stressors and strains in UK academics. Quality in Higher Education, 9(1), 2138. 
Kumarasamy, M.M., Pangil, F., \& Isa, M.F. (2015). Individual, Organizational and Environmental Factors Affecting Work-Life Balance. Asian Social Science, 11(25), 111-123.

Omar, M.K., \& Zakaria, A. (2015). Conceptualising Work-Life Balance; Extension of Work-Family Balance. Advanced Science Letters, 21(6), $2155-2158$.

Parakandi, M., \& Behery, M. (2016). Sustainable human resources: Examining the status of organizational work-life balance practices in the United Arab Emirates. Renewable and Sustainable Energy Reviews, 55(C), 1370-1379.

Rowold, J., \& Schlotz, W. (2009). Transformational and TransactionalLeadership and Followers' Chronic Stress. Kravis Leadership Institute, Leadership Review, 9, 35-48.

Shanafelt, T.D., Hasan, O., Drybye, L.N., Sinsky, C., Satele, D., et al., Sloan, J., \& West, C.P. (2015). Changes in Burnout and Satisfaction With Work-Life Balance in Physicians and the General US Working Population Between 2011 and 2014. Mayo Clinic Proceedings, 90(12), 1600-1613.

Syrek, C.J., Apostel, E., \& Antoni, C.H. (2013). Stress in highly demanding IT jobs: transformational leadership moderates the impact of time pressure on exhaustion and work-life balance. Journal Occupational Health and Psychology, 18(3), 252-261.

Valcour, M. (2007). Work-based resources as moderators of the relationship between work hours and satisfaction with work-family balance. Journal of Applied Psychology, 92(6), 1512-1523.

Wang, P., \& Walumbwa, F.O. (2007) Family friendly programs, organizational commitment, and work withdrawal: The moderating role of transformational leadership, Personnel Psychology, 60, 397-427. 